\title{
Identifying The Species, Effects And Seasonal Dynamics Of Honeybee Varroa Mites: A Newly Emerging Parasite To Ethiopian Honeybee
}

\author{
Desalegn Begna $^{1 *}$, Alemayehu Gela ${ }^{1}$, Taye Negera ${ }^{1}$, Amssalu Bezabeh ${ }^{1}$ \\ ${ }^{1}$ Oromia Agricultural Research Institute, Holeta bee research center, Ethiopi
}

Received: 22 September, 2016; Accepted: 4 November, 2016; Published: 14 November, 2016

*Corresponding author: Desalegn Begna, Senior Apiculture Researcher and process owner, apiculture technology generation President, Ethiopian Beekeepers Association, Holeta Genet, Ethiopia, Tel: (+251) 911353035/ +251961300505 (ell); Fax: +251112372115; E-mail: desalegnbegna@yahoo.co.uk

\begin{abstract}
The loss of bee colonies in recent years is a global phenomenon and Ethiopia is not exceptional. No single cause has been identified for the lose interactions of biotic and abiotic factors are speculated for the global bee colony decline. Following global warming and human population fast growth, natural forests which are used to be habitat and sources bee feed has been destroyed at fast rate. Also the contribution of bee pests and diseases is thought considerable for bee colony diminishing. Recently (2010), globally identify as causing bee colony dames bee mite varroa destructor has been reported in most beekeeping regions of Ethiopia. However, the effects of mite on bee colonies and their products, the mite strain type and its seasonal dynamics under local incident remain uncertain. Therefore, controlled experiment has been designed to unveil the basic questions with regards to the nature and the effects of the parasite under local conditions. Ten bee colonies were set up at Bako area which is $250 \mathrm{~km}$ west of Addis Ababa. Data collections were done for three years on monthly basis and collections of information were done on the parameters like the number of varroa mites on adults and brood bees and brood, pollen and nectar areas. Besides, morpho-size of the collected varroa mites were measured and compared with the morpho-sizes varroa mites collected from different localities. The study investigated negative correlation $(\mathrm{P}<-0.0 .513)$ between the number of mite and number of adult bees as well as brood, pollen and nectar areas. However, the number of mites on adult and brood bees as well as the mite's pessimistic effect varied between the colonies and the seasons. Based on morpho-size measurement, the mites were grouped into five mopho-clusters, but generally confirming all the strains belong to varroa destructor type. In spite of the presence of the parasitic varroa mite in all the bee colonies year round, all the colonies appeared to be healthy.
\end{abstract}

The result from this study has enlightened local understanding on the seasonal dynamics, effects and species of varroa mite. However, further study that entails investigations on biological/ behavior of both the parasite and the host is suggested to avail better understanding on how local bees were not affected following the number of parasailing varroa mite.

Keywords: Varroa; Ethiopia; Morpho-size; Species; Brood

\section{Introduction}

Beekeeping is an opportunity to harvest and add value to a local resource (floral nectar) to generate wealth and employment. Products from beekeeping contribute to the income and livelihood improvement of the rural people. In addition, beekeeping plays an important role in providing export commodities and environmental conservation [1]. However, the benefits from beekeeping can be affected by many biotic and abiotic factors [2-5]. Recently, the issue of honeybee health has been becoming a global research topic [2]. The recent emergence of high honeybee colony losses in many parts of the world has initiated many researches in different parts of the world [2]. Bee pathogens and parasites are identified as the most affecting honeybee health being distributed almost worldwide [6-8]. When, rigorous researches have been conducted on honeybee health aspects in the other parts of the world, the health status of honeybees in Africa remain less characterized [9, 10, 5]. In particular, the health condition of Ethiopia honeybees is poorly described as systematically reviewed by [5].

Presence of ecto-parasitic mite Varroa destructor is one of the factor globally reported effecting honeybee health $[11,12]$. This mite was previously known as Varroa jacobsoni Oudemans, 1904 and was recorded as eastern honeybees (Apiscerana Fab) ectoparasite. It was identified as Varroa destructor by a morphological study of many females collected throughout the world including Asia [13]. The parasite was first reported in South Africa in 1997 $[14,15]$ and later in 2009 in Kenya, Tanzania, Uganda and Ghana [16] and in Ethiopia in 2010 [3, 4].

However, understanding on the varroa mite strain, its seasonal dynamics and effects on local bees and their products in Ethiopia remain blurred. Therefore, given the wide spread of the varroa mite in most beekeeping areas of the country, it is paramount importance to investigate the plausible effects of this mites have both on the life and products of local honeybees.

\section{Material and Methods}

\section{Experimental places, animals and setups}

All field experimental bee colony setup was done at Bako 
sub-site of Holeta bee Research centre using honeybee race called A. m. bandassi. However, all laboratory works and data analysis were done at Holeta Bee research centre (HBRC) [17]. For the purpose, 10bee colonies in traditional beehives were obtained from beekeepers through purchasing and transferred to moveable frame beehives (Langstroth). All bee colonies were standardized to have equal condition and then monitored for having varroa mites. Subsequently, data collections on the number of adult varroa mites, brood, pollen and nectar areas were done at every 21 days for three years (2011-2013). About 200-250 live adult bee sampleswere collected from each bee colony using a wide mouth plastic jars, killed in hot water and washed in detergent-water to dislodge varroa mite. The mites were separated from dead bees using a ladle $(8-12 \mathrm{~mm}$ mesh sizes) that passes the mite together with the solution but hold the bees. Subsequently, the mites were separated from the solution using wire gauze (less than $8 \mathrm{~mm}$ mesh sizes) that pass the solution only but hold the mite. The wire gauze that is expected holding the mite was turned down and collided on the white paper and the dislodged mites was counted. Also the adult bees from which the varroa mites were recovered were counted to calculate the ration of the mite to the adult bees. In addition, a brood comb sections of $5 \mathrm{~cm} \times 5 \mathrm{~cm}$ drone and/or worker pupae areas were cut from each experimental bee colony and examined for varroa mites. A minimum of 100-200 pupae were uncapped and pulled out of their cells and examined for varroa mites. Both the number of larvae examined and the number of varroa mites recovered were recorded. Likewise, bees' collected resources (nectar and pollen) as well as brood areas measurement and estimations of adult bee population were done using standard method of Liebefelder method [18]. Statistical computations were done based on three years mean value for each of the parameters. For the varroa mite strain classification, morpho-metric measurements on the width and length of adult varroa mites were done using stereomicroscope (40x magnifications fitted with micrometers). Accordingly, body measurements of 10 varroa mites from each site were taken and their mean values were considered representing the varroa strain of the site.

\section{Results}

\section{Seasonal dynamics of varroa mite}

The mean value of monthly collected three years data indicated that adult varroa mites are present in all the experimental bee colonies throughout the years. However, the adult varroa mite population is slightly high during dry seasons of DecemberJanuary and April-June [Figure-1]. This is in line with the finding that states the varroa mite population dynamics is influenced by its host population dynamics as well as by internal and external factors.

The results from the brood bee analysis also indicated presence of varroa mites in bee colonies throughout the year. However, in the months of January, March and July the population of varroa mites recovered were low and this might be attributed to low brood rearing in these dry months. In dry season, there is low brooding tendency and this hider the growth and reproduction of the mites, which in most cases depends on the availability of bee brood [11].

\section{Effects of varroa mites on bees and bee collected resources}

Determining the level of inflicts caused by the varroa mite on bees and beeproduct is one of the objectives of this study. For the purpose, the monthly mean values of the data collected for three years over the nectar and pollen areas, bee colony population were correlated against the number of varroa mites recovered through adult and brood bee sampling.

The, bee colony strength and nectar storage areas were analysis against or the number of varroa mite recovered through adult and brood bees [Figure 2].

The result showed that the level of varroa mite is positively correlated and seasonally fluctuated along with bee occupied areas and nectar stored areas [Figure 2], suggesting bee population and bee's activities in nectar collections were not affected by the varroa mite. This result agrees with the finding that state significant positively correlation between level of varroa mites and colony size. Reproduction of varroa mites is closely synchronized with the brood development of the host and hence the colony strength [11] as well as brood less periods

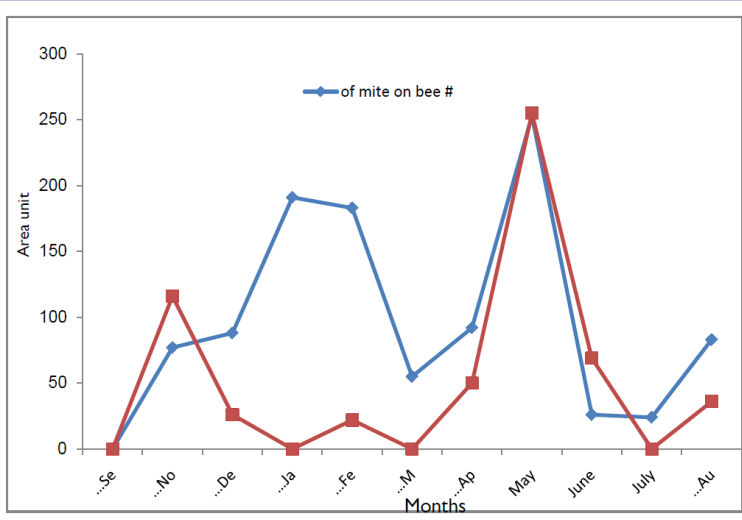

Figure 1: Seasonal dynamics of varroa mite over the months

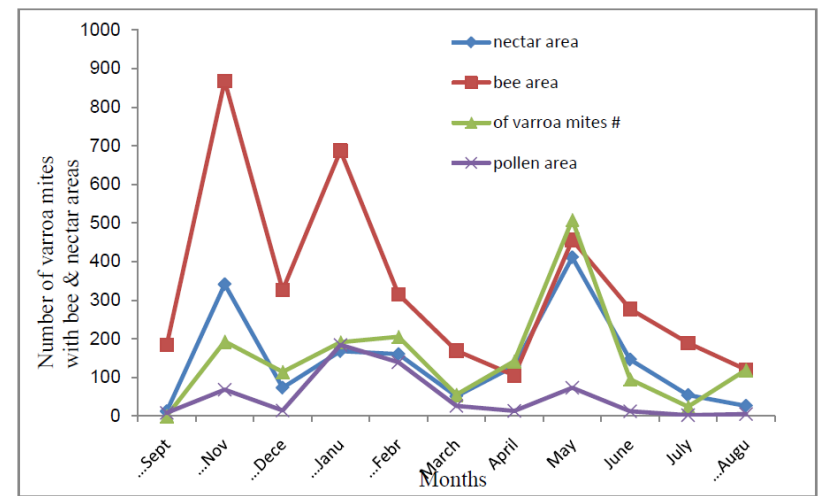

Figure 2: Effects of varroa mites on bees and their products as evaluated over the months 
reduces mite population growth and bee colonies during honey flow season are more likely to be infested by varroa mites. In fact, this is despite the killing nature and historical records the mite in causing be colony collapse on European honeybees if not chemically treated [19]. On the other hand, there are report indicating African and Africanized honeybees did not succumbed to varroa mite attacks [20-27]. Several mechanisms that may beresponsible for this tolerance have been investigated, including reduced reproduction by themites [28], greater fficiency in removing infested brood [29-30], and increased grooming behavior [31-33].

\section{Varroa strain classification}

Ten morpho-sizes (widths and lengths) of varroa mites collected for each 17 different localities were measured and compared using one way ANOVA (Duncan) to see if there are significant differences in their body sizes as a clue for different varroa mite strains. Themean results of 10 varroa body measurement revealed slight differences both in lengths and widths classifying the mites into five morpho-clusters [Table 1]. However, the differences in body size measurements of varroa mites collected from different localities is not statistically significant ( $\mathrm{P}>0.05$ ). This suggests varroa mites that are distributed to different localities belongs to similar strain and the slight body size differences can be phenotype alter due to environment.

\begin{tabular}{|l|l|l|l|}
\hline S/N & Study sources & Length $(\boldsymbol{\mu m})$ & Width $(\boldsymbol{\mu m})$ \\
\hline $\mathbf{1}$ & V. jacobsoni $[\mathbf{3 4 ]}$ & 1063.0 & 1506.8 \\
\hline $\mathbf{2}$ & V. destructor [34] & 1167.3 & 1708.9 \\
\hline $\mathbf{3}$ & V. destructor [13] & $1197.2-1200.1$ & $1775.6-1789.9$ \\
\hline $\mathbf{4}$ & Ethiopia(this data) & $1098.98-1268.61$ & $1756.89-1963.61$ \\
\hline $\mathbf{5}$ & $\begin{array}{l}\text { Average (Ethiopia, this } \\
\text { data) }\end{array}$ & 1182.69 & 1850.22 \\
\hline
\end{tabular}

Table 2: Comparative analysis of local varroa mite morphosizes with literature established sizes

\section{Conclusion and recommendation}

Based on this study, Varroa mite existed the whole season with local bees with minor differences in number across the study months. Moreover, this study identified the strain of Varroa mite that is associated with local bees is varroa destructor. The correlation between the numbers of varroa load with adult bee population, measured brood, nectar and pollen areas indicated less effects of the mite. Although further research investigation is required, from this study, it can be concluded that the effects of varroa mite is not significant. Further research that focuses on developing and implementing honeybees with genetic-based resistance solution to Varroa mites is recommended.

Table 1: Mean body width and length measurements of varroa mites collected from 17 localitie

\begin{tabular}{|c|c|c|c|c|c|c|c|c|c|c|c|}
\hline \multicolumn{7}{|c|}{ Width $(\mu \mathrm{m})$, Duncan } & \multirow{2}{*}{\multicolumn{5}{|c|}{$\begin{array}{c}\text { Length }(\mu \mathrm{m}), \text { Duncan } \\
\text { Cluster categories }\end{array}$}} \\
\hline \multirow[b]{2}{*}{ Sample places } & \multirow[b]{2}{*}{$\mathbf{N}$} & \multicolumn{4}{|c|}{ Cluster categorievs } & \multirow[b]{2}{*}{5} & & & & & \\
\hline & & 1 & 2 & 3 & 4 & & 1 & 2 & 3 & 4 & 5 \\
\hline Tefki & 10 & 1757.50 & 1757.50 & & & & 1107.50 & 1107.50 & & & \\
\hline Holeta & 10 & 1767.50 & 1767.50 & 1767.50 & & & 1119.45 & 1119.45 & & & \\
\hline Asela & 10 & 1769.45 & 1769.45 & 1769.45 & & & & 1150.00 & 1150.00 & & \\
\hline Muger & 10 & 1777.50 & 1777.50 & 1777.50 & & & & 1155.00 & 1155.00 & & \\
\hline Adama & 10 & & 1787.50 & 1787.50 & & & & 1155.00 & 1155.00 & & \\
\hline Jijiga & 10 & & 1790.00 & 1790.00 & & & & 1157.50 & 1157.50 & & \\
\hline Sebeta & 10 & & 1812.50 & 1812.50 & & & & 1165.00 & 1165.00 & & \\
\hline A/alem & 10 & & 1813.89 & 1813.89 & & & & 1165.00 & 1165.00 & & \\
\hline Mojo & 10 & & 1820.00 & 1820.00 & & & & 1167.50 & 1167.50 & & \\
\hline Jima & 10 & & 1825.00 & 1825.00 & & & & 1172.50 & 1172.50 & & \\
\hline Gedo & 10 & & & 1837.50 & & & & & 1202.50 & 1202.50 & \\
\hline Machew & 10 & & & & 1912.50 & & & & 1202.50 & 1202.50 & \\
\hline Adewa and Aksum & 10 & & & & 1943.33 & 1943.33 & & & & 1247.50 & 1247.50 \\
\hline Mekele & 10 & & & & 1950.00 & 1950.00 & & & & 1263.33 & 1263.33 \\
\hline Moyale & 10 & & & & & 1997.50 & & & & & 1295.00 \\
\hline Mean & & 1756.89 & 1792.08 & 1803.26 & 1935.28 & 1963.61 & 1098.98 & 1151.44 & 1171.79 & 1222.61 & 1268.61 \\
\hline
\end{tabular}

\section{References}

1. Krell R. value-added products from beekeeping, food and agriculture organization of the United Nations Rome, FAO, AGRICULTURAL SERVICES BULLETIN No. 124. 1996.

2. Strauss Ursula, Hannelie Human, Laurent Gauthier, Robin M. Crewe, Vincent Dietemann, et al. Seasonal prevalence of pathogens and parasites in the savannah honeybee (Apismelliferascutellata). Journal of Invertebrate Pathology. 2013;114(1):45-55.

3. Desalegn Begna. Assessment of Pesticides Use and its Economic Impact on the Apiculture Subsector in Selected Districts of Amhara Region, Ethiopia. J Environ Anal Toxicol 5:267. doi: 10.4172/21610525.1000267. 2014.

4. Desalegn Begna. Occurrences and Distributions of Honeybee 
(Apismellifera Jemenetica) Varroa Mite (Varroa destructor) in Tigray Region, Ethiopia. J Fisheries Livest Prod 2014;3(1):125. doi: 10.4172/2332-2608.1000126.

5. Desalegn Begna. Honeybee diseases and Pests research progress in Ethiopia: A review. 2015;3(1):93-96

6. Bailey L, Ball B V. Honey Bee Pathology, Academic Press, London 1991.

7. Allen M F, Ball $\mathrm{B}$ V. The incidence and world distribution of the honey bee viruses. Bee World 1996;77(3):141-162. doi: 10.1080/0005772X.1996.11099306.

8. Ellis J D, Munn P A. 2005. The worldwide health status of honey bees. Bee World. 2005;86(4):88-101. doi: 10.1080/0005772X.2005.11417323.

9. Hepburn H R, Radloff S E. Honeybees of Africa. Springer. Berlin. 1998.

10. Dietemann V, Pirk C W W, Crewe R.M. Is there a need for conservation of honeybees in Africa? Apidologie. 2009;40(3):285-295.

11. Rosenkranz P, Aumeier P, Ziegelmann B. Biology and control of Varroa destructor. J Invertebr Pathol. 2010;103 Suppl 1:S96-119. doi: 10.1016/j.jip.2009.07.016.

12. Dietemann V, Pflugfelder J, Anderson D, Charrière J D, Chejanovsky N, Dainat B et al. 2012. Varroa destructor: research avenues towards sustainable control. J Apic Res. 2012;51(1):125-132. doi: 10.3896/ IBRA.1.51.1.15.

13. Rahmani H, K Kamali, A Saboori, J Nowzari. Report and Survey of Morphometric Characteristics of Varroa destructor (Acari: Varroidae) Collected from Honeybees in Tehran Province, Iran. Research Note. J Agric Sci Technol. 2006;8:351-355.

14. Allsopp M, Govan V, Davison S. Bee health report: Varroa in South Africa. Bee Wld. 1997;78(4):171-174

15. Martin S J, Kryger P. Reproduction of Varroa destructor in South African honey bees: does cell space influence Varroamale survivorship? Apidologie. 2002;33(1):51-61

16. Fazier M, Eliud M, Tracy C, Daniel S, Baldwyn T, et al. A scientific note on Varroa destructor found in East Africa; threat or opportunity? Apidologie. 2009;41(40):463-465.

17. Holeta Bee Research center (HBRC). Report. 2010.

18. Gerig L, Lehrgangzur. Erfassung der volksstarke, Schweiz. Bienen-Ztg. 1983,106:199-204

19. Webster TC, Delaplane KS. Mites of the Honey Bee. Dadant \& Sons. Inc. Hamilton, Illinois. 2001;280 pp

20. Camazine S. Differential reproduction of the mite Varroajacobsoni (Mesostigmata, Varroidae), on Africanized and European honeybees (Hymenoptera, Apidae). Annales of the Entomological Society of America. 1986;79(5):801-803. doi: 10.1093/aesa/79.5.801 801-803.
21. Camazine S. Factors affecting the severity of Varroa jacobsoni infestations on European and Africanized bees, In: Needham GR. Africanized honeybees and bee mites. Ellis Horwood Ltd., Chichester. 1988;444-451.

22. De Jong D. Varroa and other parasites of brood. In: Honey bee Pests, Predators and Diseases (Morse RA, Flottum K). 3rd edn. A.I. Root Company. Medina, OH, USA. 1997;231-279.

23. De Jong D, Gonçalves LS. The Africanized bees of Brazil have become tolerant to Varroa. Apiacta. 1998;33:65-70.

24. Medina LM, Martin SJ, Espinosa-Montaño L, Ratnieks FL. Reproduction of Varroa destructor in worker brood of Africanized honeybees (Apismellifera). Exp Appl Acarol. 2002;27(1-2):79-88.

25. Mondragon L, Martin S, Vandame R. Mortality of mite offspring: a major component of Varroa destructor resistance in a population of Africanized bees. Apidologie. 2006;37(1):67- 74. doi: 10.1051/ apido:2005053.

26. Allsopp M. Analysis of Varroa destructor infestation of southern African honey bee populations. MS Thesis, University of Pretoria, Pretoria, South Africa. 2006.

27. Fries I, Raina S. American foulbrood and African honey bees (Hymenoptera: Apidae). J Econ Entomol. 2003;96(6):1641-6.

28. Ritter W, De Jong D. Reproduction of Varroa jacobsoni O. in Europe, the Middle East and tropical South America. Journal of Applied Entomology. 1984;98(1-5):55-57.

29. Corrêa-Marques MH, De Jong D. Uncapping of worker bee brood, a component of the hygienic behavior of Africanized honey bees against the mite Varroa jacobsoni Oudemans. Apidologie. 1998;29(3):283289.

30. Guerra JCV, Gonçalves LS, De Jong D. Africanized bees (Apis mellifera L.) are moreefficient at removing worker brood artificially infested with the parasitic mite Varroa jacobsoni Oudemans than are Italian bees or Italian/Africanized hybrids. Genet. Mol. Biol. 2000;23(1):8992.

31. Moretto G, Gonçalves LS, DE Jong D, Bichuette MZ. The effects of climate and bee race on Varroa jacobsoni Oud infestations in Brazil. Apidologie. 1991;22(3):197-203.

32. Moretto G, Gonçalves LS, De Jong D. Africanized bees are more efficient at removing Varroa jacobsoni: Preliminary data. American Bee Journal. 1991;131:434.

33. Moretto G, Gonçalves LS, De Jong D. Heritability of Africanized and European honey bee defensive behavior against the mite Varroa jacobsoni. Rev. Bras. Genet. 1993;16:71-77.

34. Anderson DL, Trueman JW. Varroa jacobsoni (Acari: Varroidae) is more than onespecies. Exp Appl Acarol. 2000;24(3):165-89. 